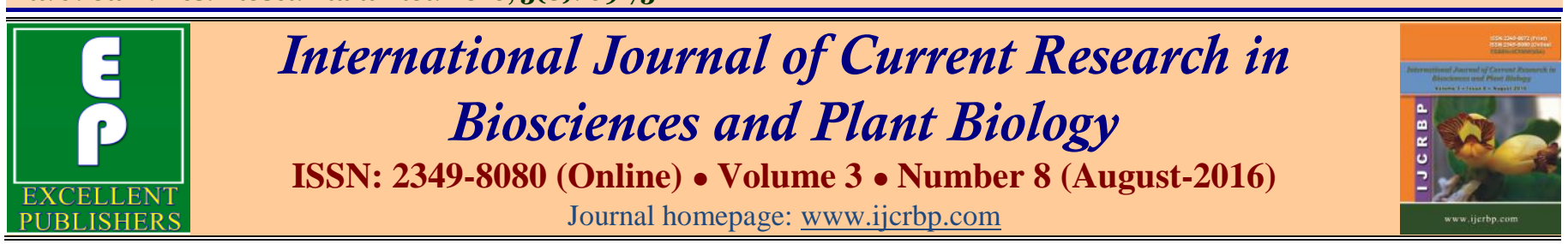

\title{
Benchmarking Loads of Lactic Acid Bacteria from Traditional Ferment of Cassava Used for the Preparation of Cassava Meal in Abidjan
}

\author{
Coulibaly Kougoman Emmanuel, ${ }^{1,2}$, Coulibaly-Kalpy Julien² ${ }^{*}$, Goualié Glossi Bernadette', \\ Akpa Esso Eric ${ }^{1}$, Niamké Sébastien Lamine ${ }^{1}$ and Dosso Mireille ${ }^{2}$
}

${ }^{1}$ Université Félix Houphouët-Boigny / Laboratoire de biotechnologie; Institut Pasteur de Côte d'Ivoire; BPV 34 Abidjan

${ }_{2}^{2}$ Institut Pasteur de Côte d'Ivoire ; Département Bactériologie-Virologie ; o1 BP 490 Abidjan 01

*Corresponding author.

\begin{abstract}
A b s t r a c t
Lactic acid bacteria became very important in the food processing industries and farms because of theirs divers properties and characters. "Magnan" is among the variety of fermented food products where they would meet. "Magnan" is a traditional ferment used for the preparation of fermented cassava meal steamed called "attiéké". Studies on the magnan showed that flora consists of molds, yeast, bacillus, and lactic acid bacteria. However, in their diversity the lactic acid bacteria involved in the fermentation remain largely unknown. In fact some studies have shown the involvement of genus Lactobacillus in this process when other associated it to the genus Leuconostoc. Also among the lactic acid bacteria, the predominant type is not known. A study to identify the genus of lactic acid bacteria mainly involved in the fermentation process used to produce "attiéké" and the $\mathrm{pH}$ gave different results: Lactobacillus $(7.2 \pm 0.7 \mathrm{log}$ (UFC/g)), Leисопоstoc $(6.7 \pm 0.6 \log$ (UFC/g)), Streptococcus $(5.8 \pm 0.9 \log (\mathrm{UFC} / \mathrm{g}))$, Lactococcus $(5.9 \pm 0.4 \log (\mathrm{UFC} / \mathrm{g}))$. It was noted that cassava peal was fermented by less loaded Pediococcus $(5.0 \pm 1.7 \log$ (UFC / g)). The $\mathrm{pH}$ of ferments ranged between $5.35 \pm 0.53$ and $5.58 \pm 0.54$.
\end{abstract}

\author{
Article Info \\ Accepted: 27 July 2016 \\ Available Online: 06 August 2016
}

\section{Keywords}

Cassava ferment

Lactic acid bacteria

Lactobacillus

Lactococcus

Leuconostoc

Magnan

\section{Introduction}

Lactic acid bacteria have an important role in food and feed. They are ubiquitous and commensal bacteria, which involved in spontaneous fermentation artisanal food. Starter's selection has made them auxiliaries manufacturing in the food industries. They are widely used as a probiotic. Today, probiotics are known as a potential stem to replace antibiotic growth promoters in livestock without creating new threats such as observed with antibiotics (Devie et al., 2005). In diversity of genus and species Lactobacillus, Leuconostoc, Lactococcus Pediococcus and Streptococcus thermophilus were recognized as those that best meet definition of lactic acid bacteria. Lactic acid bacteria are present in any fermented product meet in Côte d'Ivoire. Include the "dokounou" fermented sweet corn dough; "akassa" fermented sweet corn dough, "adjovan" fermented fish, "soumara" fermented grains of Parkia biglobosamm "attiéké" fermented cornmeal steamed cassava.

Attiéké is the main food accessible to all strata of the population. There are several types of attiéké depending on the region and the method of the preparation. Generally it is from a tapioca pulp of traditional ferment called "magnan". The magnan is generally obtained by bleaching of cassava tubers. Studies on the magnan showed that flora of magnan consists of mold, yeast, bacillus and lactic acid bacteria. The role of some of these microorganisms is well known. Bacillus and molds 
intervened in softening pulp. Lactic acid bacteria are responsible for lactic fermentation that gives a sour taste appreciated by consumers, however, in their diversity; the genus lactic acid bacteria involved mainly in this process remain unknown. In fact some studies have shown the involvement of the genus of Lactobacillus while other studies have shown both genus Lactobacillus and Leuconostoc. This study have to identify the $\mathrm{pH}$ (potential hydrogen) and the genus of lactic acid bacteria mainly involved in the fermentation process used to produce attiéké on three sites artisanal production.

\section{Materials and methods}

\section{Sampling}

Seventy one (71) samples of traditional ferment each weighing $0.5 \mathrm{~kg}$ were collected from three production sites of professional producing cassava semolina " attiéké " in Abidjan, Ivory Coast. Table 1 shows the sites and the number of samples per site. The samples were transported to the laboratory where the determination of $\mathrm{pH}$ and lactic acid bacteria counts were made.

Table 1. Sampling sites and the number of samples per site

\begin{tabular}{|c|c|c|c|c|c|c|}
\hline & Sampling 1 & Sampling 2 & Sampling 3 & Sampling 4 & Sampling 5 & Total \\
\hline Site 1 & 4 & 5 & 5 & 5 & 5 & 24 \\
\hline Site 2 & 5 & 5 & 3 & 5 & 5 & 23 \\
\hline Site 3 & 5 & 5 & 5 & 5 & 4 & 24 \\
\hline Total & 14 & 15 & 13 & 15 & 14 & 71 \\
\hline
\end{tabular}

\section{Determination of $\mathrm{pH}$}

Each sample was crushed in a sterile mortar and pestle. After homogenization, ten grams $(10 \mathrm{~g})$ was crushed and diluted in $90 \mathrm{ml}$ of distilled water and then filtered on a filter paper (filter folded diam. $190 \mathrm{~mm}$, qualitative analysis). The $\mathrm{pH}$ was measured with an electronic $\mathrm{pH}$ meter (HANNA pH meter) by immersing the electrode in the filtrate. The analysis was performed in triplicate per sample.

\section{Enumeration of lactic acid bacteria}

Twenty-five grams $(25 \mathrm{~g})$ each ground sample are put into a stomacher bag containing $225 \mathrm{ml}$ of EPT and homogenized by grinding in a Stomacher (AES Laboratoire, France). Decimal dilutions were performed to the dilution $10^{-8}$ in nine milliliters $(9 \mathrm{~mL})$ tryptone salt. The seedings were performed in duplicate for each dilution, spreading $0.1 \mathrm{~mL}$ of the inoculum. Genus of Lactobacillus and Streptococcus were counted respectively on MRS agar and M17 agar supplemented with cycloheximide $0.01 \%$.

The genus Leuconostoc and the genus Pediococcus were enumerated on MRS agar supplemented with cycloheximide $(0.01 \%)$ and vancomycin $(0.01 \%)$. Lactococcus were counted on agar Chalmers added cycloheximide $0.1 \%$. All inoculated media were placed in anaerobic jars. Petri dishes for the enumeration of the genus Lactobacillus were incubated at $37^{\circ} \mathrm{C}$, those of the genus Streptococcus to $44^{\circ} \mathrm{C}$ and those used for
Lactococcus, Leuconostoc and Pediococcus were incubated at $30^{\circ} \mathrm{C}$. The incubation period is $48 \mathrm{hrs}$.

\section{Identification of different bacterial genera}

Identification of the different genera is made by performing the main biochemical and physiological tests used for lactic acid bacteria (Pillet, 1998). Among characteristics colonies presumed counted, five were used each time. These tests include Gram stain, research catalase, cytochrome oxidase, the homo fermentation character or hetero fermentation, degradation of arginine, growth at $10^{\circ} \mathrm{C}, 15^{\circ} \mathrm{C}$ and $45^{\circ} \mathrm{C}$.

\section{Expression of results}

After confirming the method of calculating the number of each genus was carried out in accordance with paragraph 9.3.5.3 of ISO 7218: 1996 / Amd.1: 2001 (E) Microbiology of General Rules - food microbiological examination.

\section{Storage of stem}

Identified strains were kept in stock at $-24 \mathrm{C}$ in MRS broth at $30 \%$ glycerol.

\section{Statistical analyses}

The XLSTAT 2015 software was used for statistical analysis. Statistical analysis of medium loads was done according to the Kruskal -Wallis test. Multiple 
pair wise comparisons the procedure of Steel- Dwass Cristchow - Fligner has identified the differences between charges.

\section{Results}

\section{Hydrogen potential $(\mathrm{pH})$ values of cassava - ferments} of the three production sites attiéké

The mean $\mathrm{pH}$ of all 71 samples is $5.46 \pm 0.57$. The minimum and the maximum value are respectively 3.91 \pm 0.57 and $6.91 \pm 0.57$. The average $\mathrm{pH}$ of the various sites are $5.54 \pm 0.63$ for site $1,5.50 \pm 0.54$ for the site 2 and $5.34 \pm 0.53$ for the site 3 (Fig. 1). The linear trend line shows that the $\mathrm{pH}$ of the cassava - ferments vary between $5.35 \pm 0.53$ and $5.58 \pm 0.54$.

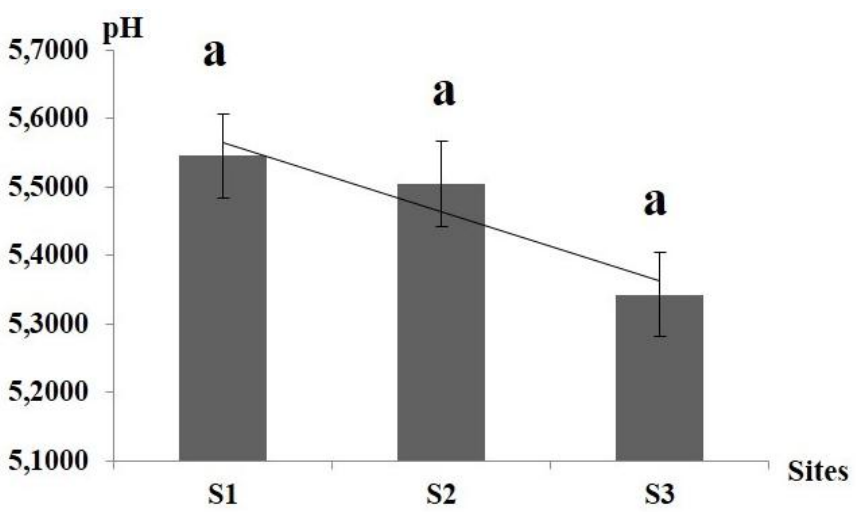

Fig. 1: Average $\mathrm{pH}$ of ferment per site.
Load of lactic acid bacteria of technological interest on the three sites

Analyzes reveal the presence of the five genus of lactic acid bacteria of technological interest. The isolation frequency is 1 for the genus Lactobacillus, Leuconostoc, Streptococcus, Lactococcus it is 0.9 for the genus Pediococcus (Table 2). The average load of lactic acid bacteria genus of cassava - ferments are shown in (Table $3)$. The different average charges for all samples for the genus Lactobacillus is $7.2 \pm 0.7 \log (\mathrm{CFU} / \mathrm{g}$ ), which is more numerous. The genus Leuconostoc is second with $6.7 \pm 0.6 \log (\mathrm{UFC} / \mathrm{g})$. The genus Streptococcus and Lactococcus statistically occupy the same position with respectively $5.8 \pm 0.9 \log (\mathrm{UFC} / \mathrm{g})$ and $5.9 \pm 0.4 \mathrm{log}$ (UFC/g). The charge of Pediococcus genus is lowest with $5.0 \pm 1.7 \log (\mathrm{UFC} / \mathrm{g})$. Fig. 2 shows the average distribution of different bacterial loads on all samples analyzed. Fig. 3 presents loads of genus studied on the site 1 . The order of distribution of the different loads on the site 1 (Fig. 3) is identical to that observed for all 71 samples. Loads of Lactobacillus and Leuconostoc are respectively $7.4 \pm 0.7 \log (\mathrm{CFU} / \mathrm{g})$ and $6.7 \pm 0.6 \mathrm{log}$ (CFU / g). Those of Streptococcus and Lactococcus are respectively $6.0 \pm 0.4 \log (\mathrm{CFU} / \mathrm{g})$ and $5.9 \pm 0.3 \mathrm{log}$ (CFU / g). The charge of the genus Pediococcus is $5.2 \pm$ $1.6 \log (\mathrm{CFU} / \mathrm{g})$. Statistical analysis showed that there is no significant difference between the loads of Lactococcus and Streptococcus. Loads of other genus are different from each other $(p<0.05)$.

Table 1. Frequency of occurrence of different genera.

\begin{tabular}{llll}
\hline $\begin{array}{l}\text { Total number of positive } \\
\text { samples }\end{array}$ & Total number of samples & $\begin{array}{l}\text { Total number of positive } \\
\text { samples }\end{array}$ & Frequency of positivity \\
\hline Lactobacillus & 71 & 71 & 1 \\
Leuconostoc & 71 & 71 & 1 \\
Streptococcus & 71 & 71 & 1 \\
Lactococcus & 71 & 71 & 1 \\
Pediococcus & 71 & 64 & 0.9 \\
\hline
\end{tabular}

Table 2. Bacterial load expressed in $\log (\mathrm{CFU} / \mathrm{g})$ by site and all sites.

\begin{tabular}{llllll}
\hline \multicolumn{7}{c}{ Bacterial $\operatorname{load} \log (\mathrm{UFC} / \mathrm{g})$} \\
\cline { 2 - 6 } & Lactobacillus & Leuconostoc & Lactococcus & Pediococcus & Streptococcus \\
\hline Site 1 & $7.4 \pm 0.7$ & $6.7 \pm 0.6$ & $5.9 \pm 0.3$ & $5.2 \pm 1.6$ & $6.0 \pm 0.3$ \\
Site 2 & $6.8 \pm 0.6$ & $6.5 \pm 0.5$ & $5.8 \pm 0.3$ & $5.5 \pm 0.5$ & $5.8 \pm 0.6$ \\
Site 3 & $7.2 \pm 0.6$ & $6.7 \pm 0.6$ & $6.2 \pm 0.5$ & $4.3 \pm 1.3$ & $5.7 \pm 1.3$ \\
All three sites & $7.2 \pm 0.7$ & $6.7 \pm 0.6$ & $5.9 \pm 0.4$ & $5.0 \pm 1.7$ & $5.8 \pm 0.9$ \\
\hline
\end{tabular}

On sites 1 and 2 loads in bacteria belonging to the genus Leuconostoc and Lactobacillus are not statistically different. These charges are higher than those of the genera Lactococcus, Streptococcus and Pediococcus (Figs. 3 and 4). Pediococcus gender is the least abundant (Table 3). 


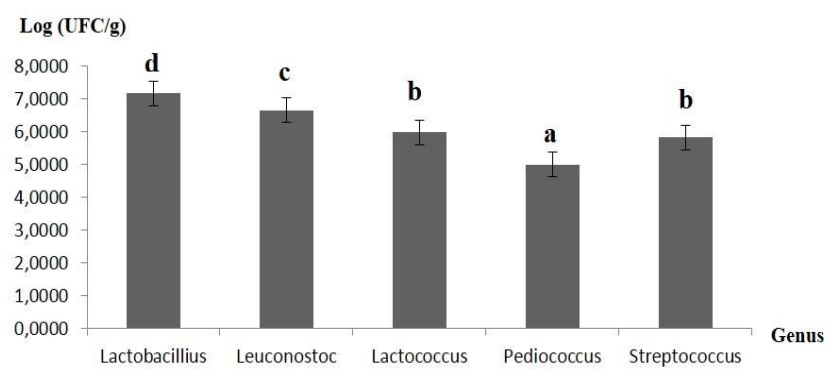

Fig. 2: Average distribution of bacterial loads in $\log$ transformed UFC per gram on all three sites.

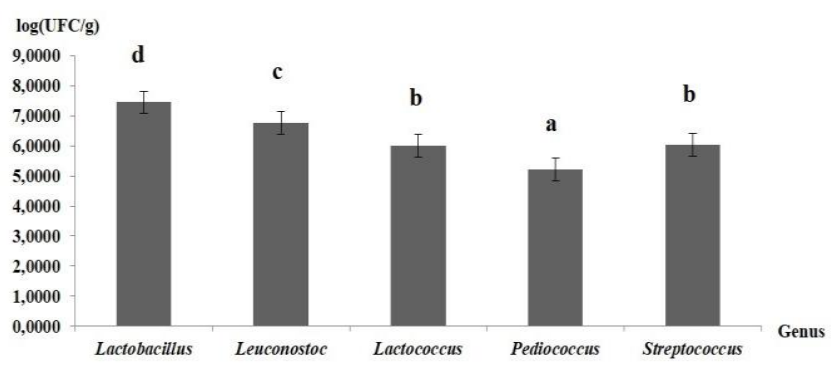

Fig. 3: Average distribution of bacterial loads in transformed UFC per gram from site 1 .

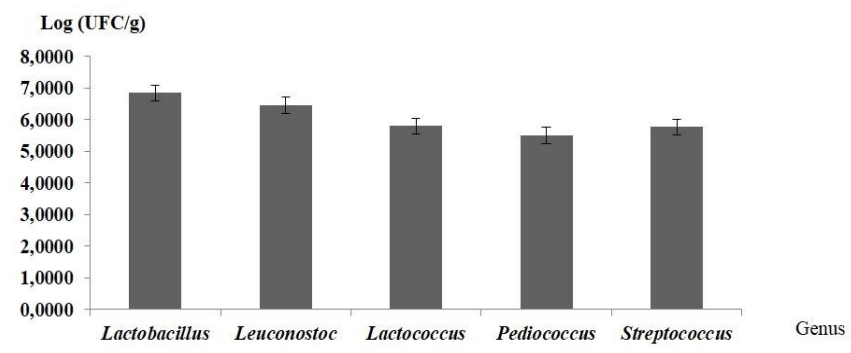

Fig. 4: Average distribution of bacterial loads in transformed UFC per gram from site 2 .

\section{Discussion}

The $\mathrm{pH}$ (potential hydrogen) cassava-ferments analyzed are acidic and have averaged between $5.35 \pm 0.53$ and $5.58 \pm 0.54$. These results are consistent with those of the study by Louembé et al (2002) which have found an acidic $\mathrm{pH}$ at the end of the fermentation process. It is the same for Djouldé et al. (2003) which showed that the $\mathrm{pH}$ of cassava ferments were acid although the original tubers have a neutral $\mathrm{pH}$. On the three sampling sites, the $\mathrm{pH}$ of ferments was not statistically different. This could be related to the fact that producers use the same manufacturing process of the ferment. Microorganisms causing $\mathrm{pH}$ lowering have a common range of growth $\mathrm{pH}$. $\mathrm{pH}$ values for optimal growth of lactic acid bacteria are generally between 5.5 and 6.5 . However there may be differences between genera and even between strains of the same species (Corrieu et al., 2008).
The 5 types of lactic acid bacteria that are Lactococcus, Streptococcus, Pediococcus, Leuconostoc and Lactobacillus were isolated in close-cassava used for the preparation of manioc "attiéké" analyzed in this study. This number is higher than the study of Assanvo et al. (2002) which had demonstrated the presence of Lactobacillus plantarum. The work of Okafor (1977), Ngaba Lee (1979) and Lei et al. (1999) revealed in turn, the presence of Leuconostoc in the ferment of cassava. This qualitative difference of lactic acid bacteria may be due to the diversity of cassava variety used for the production or the difference process used by each producer.

To our knowledge, this is the first time that the presence of the five genera of lactic acid bacteria is revealed simultaneously in a ferment-cassava, better than Lactococcus and Pediococcus had never been made. These were isolated rather other substrates (Pilet et al., 1998; Leveau et al., 1991) including corn meal.

Loads of different genera remain variable with a continuous predominance of the genus Lactobacillus and the genus Leuconostoc (Fig. 2, 3 and 4). Note also that even if the presence of Leuconostoc and Lactobacillus has been reported, no study to our knowledge has highlighted the predominance of one genus over the other four genera. This dominance can be attributed to varying $\mathrm{pH}$ in the fermentation process. Indeed, cassava has a $\mathrm{pH}$ close to neutrality 6.5 to 7.0. During the fermentation process cassava - ferments, development and the action of certain microbial groups would create $\mathrm{pH}$ conditions for the development of another bacterial group. Bacteria of the genus Lactobacillus and Leuconostoc have an optimum development of acidic $\mathrm{pH}$ between 5.5 and 6 (Corrieu et al., 2008). According Carolle Lapointe (2002), some species of Lactococcus carry out acidification during the first hours of fermentation thereafter because of their sensitivity to acidic $\mathrm{pH}$, they would be destroyed allowing resistant bacteria to grow. Magni (1999) argued that only bacteria capable of fermenting citrate have a resistance to the inhibitory effect lactate. That would justify the predominance of Lactobacillus and Leuconostoc in this study. The changes observed could be consequences of conditions productions. Although composed of the same steps and processes, they could be heavily impacted by human and environmental conditions. Most fermented products are obtained after spontaneous fermentation or by inoculation of the raw material with a portion of a previous fermentation, as is the case in the preparation of cassava-close (Assanvo et al., 2002; Yao et al., 2009). 
Also microbial succession related to the $\mathrm{pH}$, the temperature of incubation of ferment used by each producer could contribute to this selection. The species of Pediococcus genus have optimum development at temperatures between $25^{\circ} \mathrm{C}$ and $40^{\circ} \mathrm{C}$, the genus Leuconostoc between $18^{\circ} \mathrm{C}-30^{\circ} \mathrm{C}$, the Lactococcus between $25^{\circ} \mathrm{C}$ and $32^{\circ} \mathrm{C}$, Lactobacillus mesophilic 30 or $35^{\circ} \mathrm{C}$, Lactobacillus thermophilic between $40^{\circ} \mathrm{C}$ and $45^{\circ} \mathrm{C}$ and Streptococcus thermophilus $42^{\circ} \mathrm{C}-43^{\circ} \mathrm{C}$ (Corrieu et al., 2008). It has been widely demonstrated that lactic acid bacteria come from the raw material or the environment (Steinkraus; 1983; 1997; Caplice and Fitzgerald, 1999). Environmental conditions, adaptation to the substrate and the repeated use of the same utensils contribute to their selection (Assanvo et al., 2002).

\section{Conclusion}

In conclusion, this study shows that the $\mathrm{pH}$ of the "Magnan" is acidic and is located between the values 5.35 and 5.58. Moreover the bacterial genera Lactobacillus, Leuconostoc, Streptococcus, Pediococcus and Lactococcus have been highlighted. Lactobacillus is the dominant genus followed by Leuconostoc and the least being the genus Pediococcus. Although these five genres are known for their interesting technological properties, extensive studies should be performed on isolates including their antibacterial power, their enzyme profile. Allowing them use as starter in the food process or as probiotic.

\section{Conflict of interest statement}

Authors declare that they have no conflict of interest.

\section{References}

Assanvo, J.B., Agbo, G.N., Behi Y.E.N., Coulin, P., Farah, Z., 2006. Microflora of traditional starter made from cassava for "attiéké" production in Dabou (Côte d'Ivoire). Food Control. 17, 37-41.

Caplice, E., Fitzgerald, G.F., 1999. Food fermentations, role of microorganisms in food production and preservation. Int. J. Food Microbiol. 50, 131-149.
Lapointe, C., 2002. Science et technologie du lait: transformation du lait. Montréal Presses Internationales Polytechnique. 600p.

Corrieu, G., Luquet, F.M., 2008. Bactéries lactiques de la génétique aux ferments. Lavoisier/ TEC et DOC. Science et Technique Agroalimentaire. 849p.

Devie, P., Divol, A., Gilbert, G., Laurent, S., Le Goaziou, A., Olivon, M., Petit, J., 2005. Les antibiotiques dans l'alimentation animale. Rapport d'Etude, Université de Brest. http://docslide.fr/documents/anti-bio.html (Accessed on 26/07/2016)

Djoulde, D.R., Etoa, F.X., Essia, N.J.J., Mbofung, C., 2003. Fermentation du manioc cyanogène par une culture mixte de Lactobacillus plantarum et Rhizopus oryzae. Afr. J. Microbiol. Res. 5(27), 4866-4872.

Lei, V., Amoa-Awua, W.K.A., Brimer, L., 1999. Degradation of cyanogenic glycosides by Lactobacillus plantarum strains from spontaneous cassava fermentation and other microorganisms. Int. J. Food Microbiol. 53, 169-184.

Leveau, J.-Y., Bouix, M., De Roissart, H., 1991. La flore lactique In Bourgeois, C.M, , Leveau, J., Lavoisier Tec et Doc. Techniques d'analyses et de contrôle dans les industries agroalimentaires : le contrôle microbiologique, pp.152-186.

Louembé, D., Kobawila, S.C., Keléké, S., Diakabana, P., Moulassou, B.N., 2002. Rouissage des tubercules de manioc à partir de - pied de cuve \|| à base de manioc roui. Tropicultura. 20(3), 118-124.

Magni, C., 1999. Mechanism of citrate metabolism in Lactococcus lactis: Resistance against lactate toxicity at low pH. J. Bacteriol. 181(5), 1451-1457.

Ngaba, P.R., Lee, J.S., 1979. Fermentation of cassava (Manihot esculenta Crantz). J. Food Sci. 44, 1570-1572.

Okafor, N., 1977. Microorganisms associated with cassava fermentation for 'gari' production. J. Appl. Bacteriol. 42, 279-284.

Pilet, M.F., Magras, C., Federighi, M., 1998. Les bactéries lactiques. In: Manuel de Bactériologie Alimentaire. Polytechna, Paris. 308p.

Steinkraus, K.H., 1983. Hand Book of Indigenous Fermented Foods. Marcel Dekker, New York. 250p.

Steinkraus, K.H., 1997. Classification of fermented food, worldwide review of household fermentation technique. Food Control. 8, 311-317.

Yao, A.A., Egounlety, M.,Kouamé, L.P.,Thonart, P., 2009. Les bactéries lactiques dans les aliments ou boissons amylacés et fermentés de l'Afrique de l'Ouest : leur utilisation actuelle. Ann. Méd. Vét. 153, 54-65.

\section{How to cite this article:}

Coulibaly, K. E., Coulibaly, K.-J., Goualié, G. B., Akpa E. E., Niamké, S. L., Dosso, M., 2016. Benchmarking loads of lactic acid bacteria from traditional ferment of cassava used for the preparation of cassava meal in Abidjan. Int. J. Curr. Res. Biosci. Plant Biol. 3(8), 69-73. doi: http://dx.doi.org/10.20546/ijcrbp.2016.308.011 